Article

\title{
Applying the Technology Acceptance Model to Assess the Intention to Use an Aftermarket eCall Based on 112 Device for Passenger Vehicles to Ensure Sustainable Rescue Operations on European Roads
}

\author{
Alexandra Perju-Mitran ${ }^{1, *} \mathbb{\infty}$, Daniela Zirra ${ }^{2}$, George Căruţaşu ${ }^{3,4}{ }^{(}$, Alexandru Pîrjan ${ }^{3, *} \mathbb{C}$ and \\ Justina-Lavinia Stănică ${ }^{3}$ \\ 1 Management-Marketing Department, Romanian-American University, 1B Expoziţiei Blvd., \\ Sector 1, 012101 Bucharest, Romania \\ 2 Trade, Economic Integration and Business Administration Department, Romanian-American University, \\ 1B Expoziţiei Blvd., Sector 1, 012101 Bucharest, Romania; zirra.daniela@profesor.rau.ro \\ 3 Informatics, Statistics and Mathematics Department, Romanian-American University, 1B Expoziţiei Blvd., \\ Sector 1, 012101 Bucharest, Romania; carutasu.george@profesor.rau.ro (G.C.); \\ stanica.lavinia.justina@profesor.rau.ro (J.-L.S.) \\ 4 Doctoral School, University Politehnica of Timișoara, Piața Victoriei 2, 300006 Timișoara, Romania \\ * Correspondence: perju.alexandra@profesor.rau.ro (A.P.-M.); pirjan.alexandru@profesor.rau.ro (A.P.)
}

Received: 3 October 2020; Accepted: 11 November 2020; Published: 14 November 2020

\begin{abstract}
Sustainable, improved rescue operations contribute to both the safety of traffic participants and the quality of transportation services. From this perspective, we considered the need to determine to what extent the target audience, consisting of owners and/or users of road vehicles, is prepared to purchase and use an eCall In-Vehicle System (eCall IVS) for passenger vehicles, using the Technology Acceptance Model (TAM) as a research framework. To confirm the hypotheses of our research, we resorted to structural equation modelling (SEM), based on the analysis of variance (PLS-partial least squares), and we were able to validate all the causal relationships of the conceptual model, with significant path coefficients at a chosen significance threshold of $p<0.01$. Analyzing the obtained results achieved in the field of eCall IVS, one can state that the integration of these approaches with the TAM research framework gives a much more complete picture of a driver's acceptance of using an aftermarket eCall IVS, which can also serve as a starting point in aftermarket vehicle implementation and future studies.
\end{abstract}

Keywords: technology acceptance model; structural equation modelling; consumer behaviour; road traffic safety; user intention; sustainable rescue; eCall IVS

\section{Introduction}

To better understand the impact of the aftermarket installation of the eCall based on 112 devices, we will make some clarifications regarding the current state of development of this technology [1]. The commonly used definition is that the eCall IVS technology is a system installed in road vehicles, which automatically generates an emergency call (but can be activated manually by one of the vehicle occupants). The purpose of the device is to trigger rescue operations faster after a crash or collision has occurred, compared to the situation where the usual method of calling services 112 would apply. However, we must mention that in both methods, the emergency message is in compliance with the standardized protocols in effect. Presently, the eCall IVS is the only system that is truly useful after the occurrence of a serious road accident, with a sustainable effect on increasing the quality of rescue 
operations throughout the European Union [2]. After a road traffic accident occurs, the eCall device becomes activated either manually or automatically, and the accident data is provided to the public safety answering points to inform rescue services and rescue-vehicle teams [3]. Recent developments in eCall technology research also include the use of drones [4] in order to provide public safety answering points with extra information such as traffic cameras, weather stations, and thermal images, as well as other eCall features allowing video calls, accessibility for people with special needs, and even the integration of social media [5]. Such options are key in ensuring sustainable rescue operations, as well as benefits for a great variety of the market players involved, allowing network operators, service providers, and national authorities a more efficient coordination of their activities [6].

The higher the speed of technological advancement, the greater the impact on the daily lives of individuals and organizations. The implementation of a new technology involves the evaluation of two main aspects. This is the reason why many papers from the scientific literature tackle issues regarding the most recent advancements in technology and equipment, along with the most useful ecosystems of hardware and software components and developments regarding threat protection [7], as consumers adapt to evolving technologies [8].

We consider evaluating the extent to which individuals, as potential consumers, are willing to accept the innovative technology and, moreover, to use it in their daily lives. Since the 1960s, there have been concerns about developing models for assessing the degree of acceptance of new technologies (e.g., [9,10]). Currently, there is a variety of assessment models that can be applied in these types of analyses. A synthesized image of the most representative of these [11,12] is presented in Table 1.

Table 1. The most representative models for assessing technology acceptance.

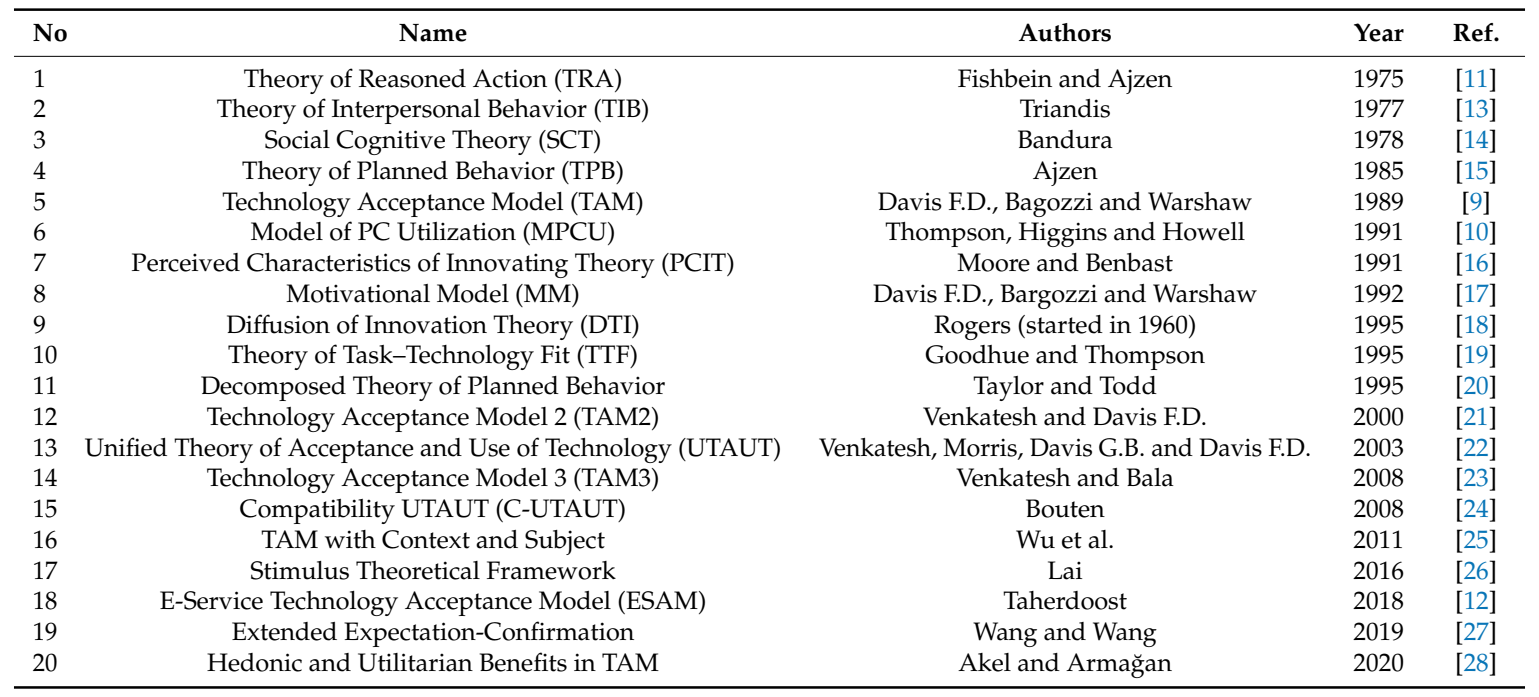

A step forward in the literature is the emergence of conclusive research, but this time of a causal nature. Many authors resort to the implementation of existing conceptual frameworks in the literature to explain the intention of individuals to use or actual behavior, the use of a device. These represent the first direction of study, namely the phenomenon of adopting technology that offers additional assistance in the event of an accident. The Technology Acceptance Model (TAM), first introduced by Fred D. Davis (1989) and later by Fred D. Davis, Richard Bagozzi, and Paul Warsaw (1989) [9,13], is the theoretical foundation for explaining and predicting the adoption of an information system by a group, individuals, or an organization (Figure 1). 


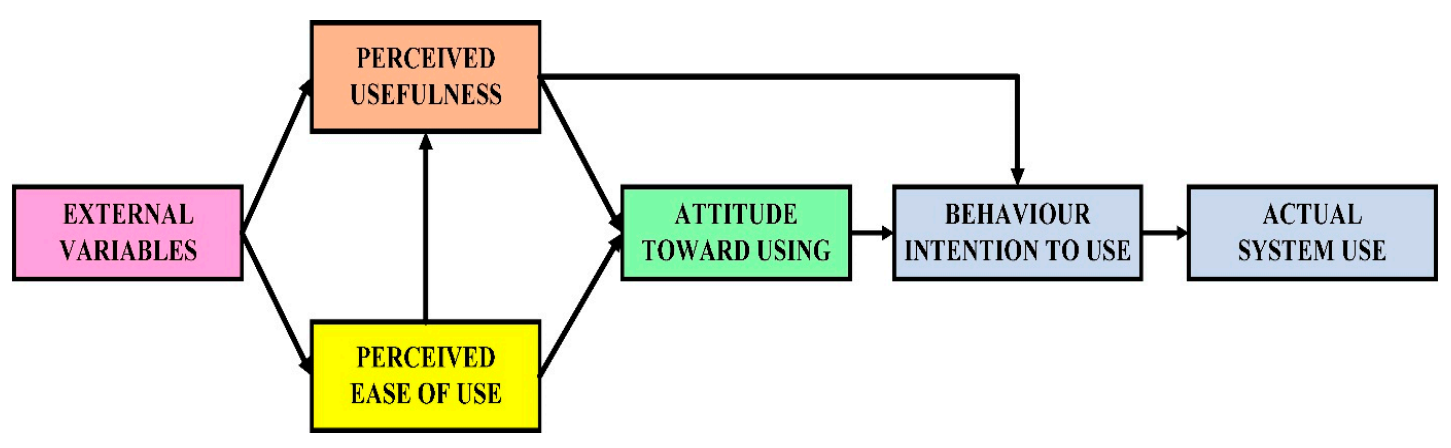

Figure 1. Technology Acceptance Model (TAM) Source: [9].

TAM appears against a background of technology development that contrasts with its low rate of adoption within organizations. The need for a reliable model meant to explain the acceptance or rejection of an information system was even more necessary since previous studies have failed [9]. TAM has gained great popularity among research and credibility on a large academic scale due to empirical research involving hundreds of studies over two decades. The emergence and development of the model during this period has made a significant contribution to the behavior of adopting an information system [29].

TAM [5,9] is the most commonly used conceptual framework for explaining and predicting the adoption of an information system by individuals [29], with over 20 meta-analyses published on effect sizes in either TAM or its extensions [30], providing rich information in the exploration of theoretical relationships. It starts from the considerations of the attitudinal theories mentioned above and identifies two fundamental beliefs of individuals, able to determine their attitude towards the information system and the intention to use the information system: perceived usefulness and perceived ease of use $[5,13]$. On the other hand, TAM is criticized for not taking into account the social influence derived from the reference groups of the individual [31]. Different factors may influence acceptance, purchase/use intention, and actual technology use, depending on what technology is introduced and what its' area of application is [32]. TAM relationships have also been validated in studies on information systems and consumer behavior literature [33-35]. Such validations motivated our replication of the TAM to adoption of the eCall IVS for aftermarket passenger vehicles.

To use the proposed system implies the adoption of a technology, namely the eCall device. Not surprisingly, many behavioral models start from the well-known research framework of TAM, which assumes that users' intention to adopt a new technology is a function given by their attitude towards the technology and its perceived usefulness [13].

Attitudinal theories $[15,36]$ support the existence of a close relationship between consumer attitudes toward behavior and behavioral intention. The same theories [36] support the formation of the affective, cognitive, and conative dimensions of the attitude based on the fundamental values and beliefs of the individuals. Based on the literature review, we identified a few fundamental consumer beliefs. It is about consumers' perceptions of the usefulness of using the eCall device, its ease of use, its personal effectiveness, defined as the extent to which the consumer believes he/she has the skills and knowledge necessary to use the device, and the consumer's compatibility with the device.

\section{Context}

We considered the need to determine to what extent the target audience, consisting of owners and/or users of road vehicles, is prepared to accept, buy, and use the eCall IVS device.

Adoption of the device had to be studied from a consumer point of view in order to determine the reasons why some individuals adopt the use of eCall devices, while others reject them.

We managed to gather 689 valid surveys from EU drivers. The differences and similarities between the chosen sample and the reference sample of the Eurostat report [37] were analyzed from the perspective of five variables: gender, age, residence, vehicle type, and vehicle age. 
Descriptive research was used to describe the socio-demographic characteristics and habits of European drivers (respondent profile) and to establish the drivers' opinions and perceptions regarding various aspects of the use of eCall IVS. Causal research was used to test the hypotheses regarding the causal relationships between the proposed variables.

We treated the attitude as a pre-purchase belief of the consumer, influenced by existing perceptions of eCall systems. Consumers initially form an attitude towards the idea of buying/using an IVS based on information from friends, family, and the media. It is not necessary for a consumer to purchase the device to form an attitude towards the eCall IVS. Nevertheless, after having made a purchase, consumers might change their pre-purchase attitude.

The life of road traffic participants is priceless. Thus, increasing road safety is a pressing priority for the European Commission, in order to achieve the targets that were set for 2030 in this area (zero fatalities and half severe injuries on EU roads, in relation to the current situation). The installation of the eCall IVS device in all road vehicles, regardless of their type, is one of the most appropriate answers to meet both the need for safety of traffic participants and to create the premises for meeting the objectives set at the European level, included in the Strategic Action Plan [38].

However, taking into account the objectives we have in mind, we will refer mainly to road transport and, in particular, to the need to continuously improve its safety. From this perspective, the investments made to increase the safety of all participants when traveling by road have multiple effects, which we can classify into two main categories:

- On the one hand, we have economic effects, such as the improvement of the economic environment, the stimulation of growth in goods and service demand, the increase and diversification in offer of companies performing post-sale services (such as repair shops) to install the eCall systems and in the offer of eCall device producers for various types of vehicles, the increase of income and profits, encouragement in the movement of people and goods, accelerating the promotion and implementation of technological progress, improving the capacity of countries to participate in the international economic circuit, and influencing the increase of economic efficiency at the level of all stakeholders.

- On the other hand, we have social effects, such as an increase in the quality of life and standard of living, creation of new jobs, development of the cultural and educational level of individuals, increase in the quality of the workforce, protection of the health and life of individuals, and environment protection by lowering fuel emissions of vehicles stuck in traffic awaiting decongestion of the accident site.

\section{Methods}

The decision-making problem of research appears against the backdrop of the need to improve traffic safety. In this context arises the need to assess adoption of the eCall device aftermarket project SAFE 2018-EU-TM-0079-S, financed by the European Commission. The implications of using an eCall device are all the greater, since the eCall aftermarket systems could have a considerable impact on reducing fatal accidents in Central and Eastern Europe [39]

Thus, there is a need of an in-depth investigation of the reasons why some individuals adopt the use of eCall devices, while others reject them. The literature is rich in such motivational studies, descriptive research, meant to study the opinions and perceptions of individuals with regard to the main advantages, but also barriers in adopting a technology (for example: [40]). For our study, to determine to what extent the target audience, consisting of owners and/or users of road vehicles, is prepared to purchase and use an eCall In-Vehicle System (eCall IVS) for passenger vehicles, we used the Technology Acceptance Model (TAM) as a research framework.

\subsection{Objectives and Hypotheses}

Amid fragmented literature and the growing need for increased road safety and fewer road fatalities, the purpose of the present study is to test and validate an intentional model, meant to explain 
the extent to which consumers intend to use the eCall device, or, in other words, the intention to purchase/use the eCall device for aftermarket/old cars. The purpose of the research is justified by the contribution made to the specialized literature but also by the practical implications at managerial level. Decreasing the number of fatal road accidents is a strategic objective of both developed and developing countries. The manifestation of this behavior can be investigated through the study of the stated intention.

Modelling the consumers' intention to continue using a technology, to buy the eCall IVS for personal use, etc., involves several central objectives as well as secondary objectives. Taking into account the purpose pursued, respectively obtaining relevant data for substantiating the analysis of benefits and costs generated by the after-market installation of the eCall IVS device at European level, in this study, we focused only on central objectives. Further analysis of consumer behavior at the level of secondary objectives will be the subject of future studies.

Purchasing an eCall device is a behavior that is not entirely volitional; it depends not only on motivational factors. There are situations in which some individuals cannot buy and use the device, because they do not know what it is used for, or they cannot afford to buy it or install it on the vehicle. In addition, not all consumers have the skills and knowledge needed to use it. These inhibitory factors are brought together under the concept of perceived behavioral control within the TPB-Theory of Planned Behavior [41], which includes both the facilitating factors and the perceived personal effectiveness of the consumer. But the mere adoption of an innovation does not implicitly imply continuity [18]. The consumer can at any time give up the purchase of the eCall device, resulting in the discontinuation of the decision to use. Thus, a second direction of study is observed in the modelling of usage behavior, namely, the studies focused on the post-adoption phenomenon.

In defining the study hypotheses, we will start from the idea that "the consumers' intention to use the eCall device", or "the consumers' intention to purchase the eCall device", is a manifestation of the continuity of the decision to use the device. Within this model, the decision of individuals to purchase the eCall device will be given by the stated behavioral intention. Intentional research allows simultaneous investigation of the influences of several explanatory variables on the declared behavioral intention. Behavioral intentions have often been treated as the conative component of attitude, which is closely linked to the affective component, which has led to a close relationship between the individual's attitude and behavioral intention [36]. As a general rule, the more favorable the attitude of the individual towards a certain behavior, the stronger the intention of the individual to perform the actual behavior $[36,42,43]$.

One of the most difficult tasks of the researcher is precisely to identify the fundamental beliefs of the individual, able to determine much of his attitude towards an object or towards a behavior [36]. In order to choose those fundamental beliefs in determining the consumers' attitude towards the adoption of the eCall device, we used a TAM that identifies two fundamental beliefs of individuals: perceived usefulness and ease of use [9]. Perceived usefulness, a concept of TAM, represents the user's conviction that the use of an information technology entails several benefits [9]. However, consumers' beliefs about the usefulness of the eCall device are not only a determining factor in adoption [44,45], but also a factor in the continuity of this behavior.

The second fundamental belief of individuals postulated by TAM as having a determining effect on the attitude of individuals towards a computer system is the ease of use. This concept represents the extent to which users of a computer system perceive its use as effortless [9]. According to TAM, the individual's conviction about the ease of use of the information system determines his attitude towards the use [46]. In other words, the easier it is to use a device, the more consumers have a more favorable attitude towards this device. Even if they perceive the usefulness of new technology, some users may refuse to adopt it precisely because it is difficult to use, hence the existence of a direct and positive link between ease of use and perceived usefulness [46]. The purpose of the study is to test and validate an intentional model meant to explain the extent to which consumers intend to purchase the eCall device. 
A list of the established central objectives and hypotheses is presented in Table 2.

Table 2. Central objectives and hypotheses.

\begin{tabular}{|c|c|c|c|}
\hline Central Objectives & Objective Description & Hypothesis & Hypothesis Description \\
\hline O1 & $\begin{array}{l}\text { Studying the effect of consumer attitude } \\
\text { towards the use of an eCall device on their } \\
\text { intention to use it. }\end{array}$ & H1 & $\begin{array}{l}\text { There is a direct and positive relationship } \\
\text { between consumers' attitude towards the } \\
\text { eCall IVS and their intention to use } \\
\text { the device. }\end{array}$ \\
\hline $\mathrm{O} 2$ & $\begin{array}{l}\text { Studying the effect of consumer } \\
\text { perceptions on the usefulness of using the } \\
\text { eCall device on their intention to use it. }\end{array}$ & $\mathrm{H} 2$ & $\begin{array}{l}\text { There is a direct and positive relationship } \\
\text { between consumers' perceptions of eCall } \\
\text { IVS usefulness and their intention to use } \\
\text { the device. }\end{array}$ \\
\hline O3 & $\begin{array}{l}\text { To study the effect of consumer } \\
\text { perceptions on the usefulness of using the } \\
\text { eCall device on their attitude towards the } \\
\text { use of the device. }\end{array}$ & $\mathrm{H} 3$ & $\begin{array}{l}\text { There is a direct and positive relationship } \\
\text { between consumers' perceptions of eCall } \\
\text { IVS usefulness and their attitude towards } \\
\text { using the device. }\end{array}$ \\
\hline $\mathrm{O} 4$ & $\begin{array}{l}\text { Studying the effect of consumer } \\
\text { perceptions on the ease of use on their } \\
\text { attitude towards the use of the device. }\end{array}$ & $\mathrm{H} 4$ & $\begin{array}{l}\text { There is a direct and positive relationship } \\
\text { between consumers' perceptions of the } \\
\text { ease of use of the eCall IVS and their } \\
\text { attitude towards the device. }\end{array}$ \\
\hline O5 & $\begin{array}{l}\text { Studying the effect of consumer } \\
\text { perceptions on the device's ease of use on } \\
\text { their perceptions regarding the usefulness } \\
\text { of the device. }\end{array}$ & H5 & $\begin{array}{l}\text { There is a direct and positive relationship } \\
\text { between consumers' perceptions of the } \\
\text { ease of use of the eCall IVS and their } \\
\text { perceptions of the device usefulness. }\end{array}$ \\
\hline
\end{tabular}

The conceptual model of the study involves defining and determining the measurements of 4 latent variables: the consumers' intention to buy the eCall device, the attitude towards the use of the device, the perceived usefulness, and the ease of use. The first step in determining the measurements of the latent variable "consumers' intention to continue use/buy eCall" is to define it at both general and specific levels.

A singular behavior involves an action, directed at a target, executed in a certain context, at a certain point in time $[36,47]$. The principle of compatibility of Fishbein and Ajzen implies that the measures of intention and behavior include the same action, target, context, and time, which have been defined either at a specific or general level [36].

Even if the conceptual model does not imply the existence of an endogenous variable "effective behavior", this correspondence will be followed as in the case of a longitudinal study. As defined above, "buy" is the action (use of the device), directed at a target (in order to satisfy individual wishes and needs), executed in a certain context in which the individual has a choice between using the device or driving a vehicle without a device, an action that takes place at a certain point in time (when the need or desire arises). According to the recommendations of Fishbein and Statsson [48], consumers' intention to buy the eCall device is a single (dependent), one-dimensional reflective construct, also called first order, containing a set of three items (intention as expectation, intention as plan, expressed intention). This three-item plural expression of intention also allows a limitation of errors specific to declared preference surveys.

Again, the principle of compatibility of Fishbein and Ajzen implies that measures of attitude and behavior include the same action, same target, context, and time, which have been defined either at a specific or general level [36]. Thus, at the specific level, the attitude of the consumers towards the idea of using the eCall device will be studied, in order to satisfy some wishes or needs, and at the general level, the attitude of the consumers will be studied towards the eCall device. When the two indicators comply with the principle of compatibility, they should correlate with each other [47].

Fishbein and Ajzen differentiate between attitude toward an object and attitude toward behavior [36]. According to the authors, the attitude towards an object represents the affective evaluation of the individual towards a specific object; the attitude towards the behavior represents the individual evaluation of a specific behavior that includes the object. Theories in the field of information systems have accepted Fishbein and Ajzen's (1975) definition of attitude as an evaluative affect that 
represents the positive or negative feelings of the individual towards the achievement of the target behavior $[9,22]$.

Based on these considerations, attitude is the measure of the evaluative affect that an individual associate with the idea of using the eCall device (definition adapted to the specifics of the study after [46]). Based on these considerations, the attitude variable is constructed as a one-dimensional reflective construct, with a set of four items that do not differentiate between the instrumental and the experiential component of the attitude.

Perceived usefulness is a concept of TAM and represents the individual's conviction that using a technology brings certain benefits [9]. Aftermarket adoption of an eCall device implies the use of a new technology that individuals would not be willing to accept without its benefits. Perceived usefulness is closely linked to another concept in the literature: the relative advantage, a specific concept of Innovation Dissemination Theory, representing the degree to which an innovation is perceived as an amplification or improvement of the current supply [18]. As a mode of construction, the variable "perceived usefulness" was constructed as a one-dimensional reflective construct, consisting of a set of four items.

Ease of use is a concept of the TAM and represents the extent to which users of an information system perceive a low degree of effort to use it [9]. Adapted to the study of the usage behavior of the eCall device, we will define the perceived ease of use as the consumer's beliefs about the low degree of effort required to use the device. The measures of perceived ease of use were adapted after Davis (1989), considering the measures already adapted for the study of the ease of use. As a mode of construction, the variable "ease of use" was constructed as a one-dimensional reflective construct, consisting of a set of three items.

Through the elaborated questions it was desired to obtain information regarding the socio-demographic profile of the driver and their driving habits, but also their opinions, beliefs, and attitudes related to the use of an eCall device. Several types of questions were used, depending on the nature of the question: closed, dichotomous, and multiple answer questions. In the case of questions with scaled answers formed based on the 7-category Likert measurement scale, the respondents chose the level of agreement regarding the statements.

The first question, also called the filter question, had the role of selecting those respondents who meet the qualifications to be part of the investigated sample, i.e., whether they hold a driving license. The rest of the questions were grouped by topic, in sections, arranged in a logical structure. The pretesting of the questionnaire was carried out among 256 respondents, with the characteristics of the investigated population, to identify possible confusions in the elaboration of the questions.

The participants in the pre-survey of the questionnaire were asked to take notes regarding the duration of completion of the entire questionnaire and the difficulty level of the questions, but also to provide feedback regarding any improvements or errors/failures of the web platform. Upon administering the questionnaire, respondents were also briefed on the aftermarket eCall in-vehicle system, its features, and its functionalities, as the survey included a presentation of the system and was also administered at automobile tradeshows, transportation conferences and other events where the project partners were involved in the presentation of the eCall IVS. The structure of the questionnaire is presented in the Supplementary Materials.

\subsection{Sampling}

Given that the purpose of the research is to study the consumers' intention to purchase the eCall device, the target population was delimited by certain fundamental characteristics: the possession of a driver's license and a vehicle (or at least using a vehicle at the work place). Thus, only those consumers who own a driver's license and drive a car represent the target population of the research. There are situations, as in the present case, when there are no sampling frames for the target population of the research. There is no database of all persons with driving license valid in 2019 and their contact information, hence our use of filter questions to correctly identify the elements of the target population. 
Depending on the time criterion, the sampling method is a traditional one, which implies that the entire sample must be established before the data is collected. Moreover, the sampling method is a non-return method, which allows an element to be included only once in the research sample. Depending on the degree of involvement of the researcher in the selection of the sample, the sampling method is an improbable one, in which case the probability of selecting a unit from the researched population is not known before the data collection.

This sampling method was chosen due to the impossibility of using a sampling framework. The cases in which the sampling framework cannot be determined require the use of an improbable sampling method [49]. One of the most commonly used non-probability sampling methods is random sampling, which involves finding respondents in places where they can be found, places that are within the researcher's reach [50]. By determining the sample size, it was desired to comply with the requirements regarding the size in order to make it possible to extrapolate the research results to the entire population surveyed. To this end, we started from the concept of "proportion" that describes the studied community to determine the sample size in relation to the investigated attributes:

- $\quad \mathrm{n}=$ the sample size

- $\quad t=$ coefficient associated with the probability of guaranteeing the research results (confidence level)

- $\quad p=$ the percentage weight of the components of the sample that are characterized by a certain attribute

- $\quad \mathrm{q}=$ the percentage weight of the components of the sample that are not characterized by the attribute $p$, being determined as a relation $(1-p)$

- $\quad \mathrm{e}=$ margin of error

Given that the sample will be used to investigate consumers' intention to use the eCall device, a "driving license" attribute was chosen as the key attribute. According to the Eurostat report [37], in the EU there is a 294,966,256 vehicles stock. Based on these statistics, one can calculate the weight of the persons who would be targeted in purchasing the eCall device among the drivers; the current population in the EU stands at roughly 513,481,690 [37]. Given that the sample is used to investigate consumers' intention to use the eCall based on the 112 IVS, we used a "driving license" key attribute as a filter. Based on these official data, the value of attribute " $p$ " will be $p=0.575$, and that of attribute $\mathrm{q}$ will be $\mathrm{q}=0.425$. It was decided to work under a confidence interval of 0.05 , corresponding to a probability of guaranteeing $99 \%$ results and a margin of error of $+/-5 \%$. Thus, the sample size will be:

$$
n=2.58^{2} \times 0.575 \times 0.425 / 0.05^{2}=1.626 / 0.0025=650.66
$$

- Based on the above considerations, the research sample must include no less than 651 observation units to respect the principle of representativeness for the investigated population. Due to the fact that we managed to gather 689 valid surveys, the final sample size remained at 689 .

It is also worth mentioning that at a standard $p$ value of 0.5 , the sample value would be $n=666$ respondents; therefore, our final sample size remains valid. The differences and similarities between the chosen sample, consisting of 689 respondents and the reference sample of the Eurostat report [37], were analyzed from the perspective of four variables: gender, age, residence, vehicle type, vehicle age. Regarding the gender of the respondents, there are no significant differences, the number of female respondents being close to the number of male respondents. A description of the defining characteristics of the respondents is provided in Section 3.3.1.

\subsection{Examination and Validation of Data}

Missing values may be random, when respondents skip a question due to inattention, or non-random, when they choose not to answer a certain question for different reasons [51]. This fact is also confirmed by the analysis of missing values conducted in the statistical program WARP PLS 
version 16. By pretesting the data, the program shows the existence or non-existence of missing values within each variable.

Extreme multivariate values represent the extreme scores for two or more variables or an atypical score pattern [52]. The extreme multivariate values in WarpPLS can be observed in the analysis of the path coefficients between two latent variables, when we encounter absurd values of the significance threshold, under the conditions in which the sample is representative [53]. Extreme multivariate values can be identified through the diagrams of linear or non-linear relationships between the latent variables.

Techniques for modelling structural equations based on variance analysis (PLS) do not imply the existence of normally distributed data [53-56]. PLS uses the non-parametric bootstrapping technique to obtain the standard errors required for hypothesis testing and assumes that the sample distribution is a reasonable representation of the target population distribution [53-55]. Due to the fact that the collected data does not respect the principle of normality, PLS is the best method of data analysis.

\subsubsection{Respondents Profile and Representativeness}

Drivers have different socio-demographic characteristics and buying habits. For a better knowledge of their defining characteristics, the profile of the respondents was established.

The complete profile of potential consumers, who have a driver's license and who have answered yes to the request to participate in the survey, is presented in Table 3. It can be noticed that there are no significant differences in the gender of the respondents, $45.42 \%$ being women and $54.57 \%$ being men.

Table 3. Respondent profile.

\begin{tabular}{|c|c|c|}
\hline Characteristics & Frequency & Percentage ( $\%)$ \\
\hline \multicolumn{3}{|l|}{ Age } \\
\hline $16-30$ & 284 & 41.21 \\
\hline $31-40$ & 209 & 30.33 \\
\hline $41-50$ & 102 & 14.8 \\
\hline $51-60$ & 73 & 10.59 \\
\hline Over 60 & 21 & 3.04 \\
\hline Prefer not to answer & 0 & 0 \\
\hline \multicolumn{3}{|l|}{ Gender } \\
\hline Female & 313 & 45.42 \\
\hline Male & 376 & 54.57 \\
\hline \multicolumn{3}{|l|}{ Residence } \\
\hline Urban & 552 & 80.11 \\
\hline Rural & 137 & 19.88 \\
\hline \multicolumn{3}{|l|}{ Vehicle Type } \\
\hline Car or taxi & 601 & 87.22 \\
\hline Motorcycle & 29 & 4.2 \\
\hline Moped & 5 & 0.72 \\
\hline Lorrie & 0 & 0 \\
\hline HGV & 11 & 1.59 \\
\hline Bus or coach & 38 & 5.51 \\
\hline Other & 5 & 0.72 \\
\hline \multicolumn{3}{|l|}{ Vehicle Age } \\
\hline Less than 5 & 242 & 35.12 \\
\hline More than 5 but less than 10 & 223 & 32.36 \\
\hline More than 10 but less than 15 & 190 & 27.57 \\
\hline Over 15 & 34 & 4.93 \\
\hline \multicolumn{3}{|l|}{ Driving Frequency } \\
\hline Daily & 399 & 57.91 \\
\hline Several times a week & 149 & 21.62 \\
\hline Several times a month or on weekends & 94 & 13.64 \\
\hline Occasionally (less than once a month) & 47 & 6.82 \\
\hline \multicolumn{3}{|l|}{ Drive Area } \\
\hline In the city/village & 529 & 76.77 \\
\hline Outside the city/village & 154 & 22.35 \\
\hline
\end{tabular}


Very large differences appear within the demographic variable "age". Most of the respondents are between 16 and 30 years old: $41.21 \%$ are between 16 and 30,30.33\% between 31 and $40,14.8 \%$ between 41 and 50,10.59\% are between the ages of 51 and 60, and 3.04\% are over 60 years old.

Regarding their place of residence, $80.11 \%$ of the respondents live in the urban environment, and $19.88 \%$ live in rural areas.

The vast majority of respondents, namely $80.11 \%$, reside in the city; only $19.88 \%$ declared that they reside in the rural environment. Regarding their vehicle types, as expected, the majority of respondents drive passenger vehicles $(87.22 \%)$, described as cars or taxis. $5.51 \%$ drive a bus or coach, followed by motorcycles at $4.2 \%$ and HGVs at $1.59 \%$. Respondents are more evenly distributed according to the age of their vehicles. Regarding vehicle age, most of the respondents, namely $35.12 \%$ of the total respondents, declared that their vehicle is less than 5 years old, followed by less than 10-year-old vehicles (32.36\%) and more than 10 but less than 15 years old (27.57\%). At the opposite pole are those who own vehicles that are over 15 years old $(4.93 \%)$.

With regards to driving frequency, most of the respondents, $57.91 \%$, drive daily, followed by those who drive several times a week, representing $21.62 \%$.

The main area of driving is in the city/village (76.77\%), with only $22.35 \%$ declaring that they most often drive outside the city/village.

\subsubsection{Measurement Accuracy}

In any data set there will be a certain amount of error that must be minimized for better accuracy of the investigated phenomenon [57]. Moreover, no measuring instrument is completely safe, and there is always the possibility of a measurement error [57]. The measurement error represents a potential threat to the validity of the empirical results, which is why it is necessary to validate the measuring instrument before presenting the research results [58].

The most commonly used method for evaluating the accuracy of measurements is internal consistency [59]. The popularity of internal consistency as a method for determining accuracy is given by its ability to measure the accuracy of measurements from a single administration of the questionnaire [60].

It starts from the idea that the scales formed of several items are effective only if they behave in a homogeneous manner, measuring the same variable [61]. Thus, internal consistency ensures that all items of a variable consistently contribute to determining the measurement of a particular variable [62].

Usually, internal consistency is measured using Cronbach Alpha coefficients [59,61,62], the technique of calculating coefficient estimates medium accuracy based on all the ways of dividing the set of items into two parts.

The Cronbach Alpha technique correlates each individual item with the other items of the same construct and with the overall score [62]. The Cronbach's Alpha coefficient $(\alpha)$ is calculated based on the formula:

$$
\propto=\frac{K}{K-1}\left(1-\frac{\sum_{i=1}^{K} \sigma_{y_{i}}^{2}}{\sigma_{X}^{2}}\right)
$$

where $K$ represents the number of items, $\sigma_{X}^{2}$ represents the variation of the total scores observed, and $\sigma_{y_{i}}^{2}$ represents the variation of the item " $i$ " [63].

The Cronbach Alpha coefficient can take values between 0 and 1 . There are disputes over the value of Cronbach Alpha coefficients indicating acceptable or adequate accuracy of measurements [64] (p. 221).

Most researchers cite Nunnally's recommendation for an acceptable threshold of over 0.7 [64], (p. 221). Nunnally recommends a Cronbach coefficient value of over 0.7 for preliminary research and over 0.8 for applied research [65] (p. 245).

Internal consistency can be regarded as an inappropriate term, since it is not based only on the average correlations between the items, but also on the number of items that make up that variable [65], 
which is why a variable made of 10 items will have a better internal consistency than a variable consisting of three items. Thus, determining the accuracy of measurements based on Cronbach Alpha coefficients will be done if the number of indicators is limited [64] (p. 222).

To test the accuracy of each variable used in the present research, we used the WARP $=$ PLS software, version 6.0. From the output generated by the program, we compiled Table 4 .

Table 4. Cronbach's alpha coefficients.

\begin{tabular}{ccccc}
\hline Variable & Ease of Use & Perceived Usefulness & Attitude & Intention \\
\hline Coefficient & 0.875 & 0.876 & 0.912 & 0.897 \\
\hline
\end{tabular}

In the case of all variables, the Cronbach Alpha coefficient indicates a good internal consistency of this scale [65]. The total correlation of each item with the cumulative score of the other items supports this assertion.

Furthermore, by eliminating one of the items in the construct, we obtain a Cronbach Alpha coefficient lower than that generated by all items. Thus, it is not necessary to give up any item of the construction [66].

Another way to check the internal consistency of items is represented by measurement of composite reliability [53], which represents a measure of the overall accuracy of a set of items that measure the same construct [67].

Composite reliability coefficients can take values from 0 to 1 , recommending a value of composite reliability coefficients of over 0.6 [58,67] and 0.7 [65], respectively, which indicate acceptable internal consistency.

To test the accuracy of the measurements by the composite reliability coefficients, we used the statistical software WarpPLS, version 6.0. The results obtained are presented in Table 5.

Table 5. Composite reliability coefficients.

\begin{tabular}{ccccc}
\hline Variable & Ease of Use & Perceived Usefulness & Attitude & Intention \\
\hline Coefficient & 0.923 & 0.915 & 0.938 & 0.936 \\
\hline
\end{tabular}

All coefficients of the composite reliability exceed the recommended minimum threshold of 0.6 [67], having values between 0.915, in the case of the variable "perceived usefulness", and 0.938 in the case of "attitude". As with the Cronbach's Alpha coefficients, the composite reliability coefficients indicate a good consistency of measurements.

\subsubsection{Measurement Validity}

Validity refers to the extent to which the measurements adequately reflect the real meaning of the investigated concept [68]. Unlike exploratory factorial analysis, in the case of structural equation modelling (SEM) based on variance analysis, namely PLS, a confirmatory factorial analysis is performed, starting with certain theoretically anticipated factors in an attempt to confirm that the set of items correspond to them [69] (p. 92).

The accuracy of this pre-specified model is examined to determine convergent and discriminant validity [69] (p. 92). Convergent validity evaluates the relationship between the scores of the proposed indicators to measure a concept or construct. If all indicators of a construct show similar results [70] and significantly load on the construct for which they were defined [69], then the measuring instrument is assumed to have good convergent validity.

Convergent validity was tested with the statistical software WarpPLS, version 6.0, which generates factor loadings and cross-loadings based on structure matrix, pattern matrix, and a combination of the two types of matrices, the result of which is three methods being generated in separate tables. 
Rotation has been viewed as a set of methods in factorial analysis, whereby the researcher tries to associate the calculated factors with theoretical entities, regardless of whether the researcher expects them to correlate or not.

The oblique rotation methods are most appropriate in a SEM (structural equation modelling) analysis, since it starts from the existence of certain correlations between the latent variables, in the absence of which the link coefficients would be insignificant [53].

Thus, the first table analyzed will be the one of the factor loadings and the cross loadings from the pattern matrix. They were obtained from the transformation of a structure matrix (structure matrix) by the oblique rotation method, also called Promax [53].

In Table 6, we observe that each set of items loads very well within its defined construct. For example, within the INT construct, representing consumers' intention to purchase/use the eCall IVS, factor loadings take values from 0.864 to 1.01, while cross-loadings are very small. These values indicate that the elements of the INT construct, namely INT1, INT2, INT3 load efficiently inside the construct and very weak outside of it.

Table 6. Pattern loadings and cross-loadings.

\begin{tabular}{ccccc}
\hline & Ease of Use & Perceived Usefulness & Attitude & Intention \\
\hline EOU1 & 0.9 & 0.078 & -0.014 & -0.086 \\
EOU2 & 0.962 & -0.054 & -0.077 & 0.049 \\
EOU3 & 0.819 & -0.024 & 0.094 & 0.037 \\
USE1 & 0.091 & 0.936 & 0.012 & -0.182 \\
USE2 & -0.065 & 0.969 & -0.079 & -0.025 \\
USE3 & 0.011 & 0.808 & -0.222 & 0.288 \\
USE4 & -0.039 & 0.701 & 0.283 & -0.07 \\
ATTIT1 & -0.008 & 0.081 & 0.787 & 0.068 \\
ATTIT2 & -0.015 & 0.015 & 0.881 & -0.004 \\
ATTIT3 & 0.064 & -0.161 & 0.996 & 0.001 \\
ATTIT4 & -0.044 & 0.07 & 0.891 & -0.066 \\
INT1 & 0.031 & 0.094 & -0.054 & 0.864 \\
INT2 & 0.03 & -0.125 & -0.017 & 1.01 \\
INT3 & -0.062 & 0.035 & 0.071 & 0.855 \\
\hline
\end{tabular}

Table 7 displays the factor loadings and the cross loadings from the structure matrix. As the matrix contains Pearson correlations between indicators (items) and latent variables, this is not significant before rotation in the context of validation of the measuring instrument [53].

Table 7. Structure loadings and cross loadings (Structure matrix).

\begin{tabular}{ccccc}
\hline & Ease of Use & Perceived Usefulness & Attitude & Intention \\
\hline EOU1 & 0.898 & 0.488 & 0.479 & 0.33 \\
EOU2 & 0.907 & 0.433 & 0.448 & 0.358 \\
EOU3 & 0.878 & 0.503 & 0.539 & 0.415 \\
USE1 & 0.51 & 0.876 & 0.628 & 0.462 \\
USE2 & 0.401 & 0.851 & 0.588 & 0.503 \\
USE3 & 0.436 & 0.834 & 0.578 & 0.621 \\
USE4 & 0.461 & 0.855 & 0.709 & 0.539 \\
ATTIT1 & 0.492 & 0.691 & 0.891 & 0.612 \\
ATTIT2 & 0.472 & 0.651 & 0.88 & 0.563 \\
ATTIT3 & 0.518 & 0.612 & 0.91 & 0.563 \\
ATTIT4 & 0.457 & 0.654 & 0.875 & 0.534 \\
INT1 & 0.404 & 0.6 & 0.587 & 0.904 \\
INT2 & 0.365 & 0.513 & 0.555 & 0.927 \\
INT3 & 0.351 & 0.583 & 0.604 & 0.901 \\
\hline
\end{tabular}

Comparing both the factor loadings and the cross loadings of the template matrix and the structure matrix, we observe that they tend to be higher within the structure matrix. This is because within the template matrix, the loadings reflect both the unique relationship between item and factor, as well as the relationship between item and common variance between factors [54]. 
In order for the measurements to be well defined, that is, to respect the principle of convergent validity, it is necessary that the $p$ values associated with factor loadings be less than 0.5 and the loadings equal to or greater than 0.5 [71].

Indicators for which these criteria are not met are excluded from the model. A more permissive case is that of the formative variables, for which this rule does not apply [53]. Table 6 shows factor loadings above 0.5 and cross loadings below 0.5 , confirming the divergent validity of the measurements.

Table 8 shows the combined loadings and cross-loadings in the pattern matrix [53]. Due to the fact that the loadings come from an unstructured matrix, they will have values between -1 and 1 . In order to allow the convergent validity of the measurements, the loadings must be equal to or greater than 0.5 , and the $p$ values associated with the loadings must be more less than 0.05 [71,72].

Table 8. Combined loadings and cross-loadings.

\begin{tabular}{ccccccc}
\hline & Ease of Use & Perceived Usefulness & Attitude & Intention & SE & $p$ Value \\
\hline EOU1 & 0.898 & 0.078 & -0.014 & -0.086 & 0.035 & $<0.001$ \\
EOU2 & 0.907 & -0.054 & -0.077 & 0.049 & 0.035 & $<0.001$ \\
EOU3 & 0.878 & -0.024 & 0.094 & 0.037 & 0.035 & $<0.001$ \\
USE1 & 0.091 & 0.876 & 0.012 & -0.182 & 0.035 & $<0.001$ \\
USE2 & -0.065 & 0.851 & -0.079 & -0.025 & 0.035 & $<0.001$ \\
USE3 & 0.011 & 0.834 & -0.222 & 0.288 & 0.035 & $<0.001$ \\
USE4 & -0.039 & 0.855 & 0.283 & -0.07 & 0.035 & $<0.001$ \\
ATTIT1 & -0.008 & 0.081 & 0.891 & 0.068 & 0.035 & $<0.001$ \\
ATTIT2 & -0.015 & 0.015 & 0.88 & -0.004 & 0.035 & $<0.001$ \\
ATTIT3 & 0.064 & -0.161 & 0.91 & 0.001 & 0.035 & $<0.001$ \\
ATTIT4 & -0.044 & 0.07 & 0.875 & -0.066 & 0.035 & $<0.001$ \\
INT1 & 0.031 & 0.094 & -0.054 & 0.904 & 0.035 & $<0.001$ \\
INT2 & 0.03 & -0.125 & -0.017 & 0.927 & 0.035 & $<0.001$ \\
INT3 & -0.062 & 0.035 & 0.071 & 0.901 & 0.035 & $<0.001$ \\
\hline
\end{tabular}

From Table 8, we can see that each item loads very well inside the construct, with loading values over 0.5 , at $p<0.001$, thus meeting the convergent validity criteria.

Discriminant validity determines the extent to which one latent variable differs from the other latent variables in the model [56]. Discriminant validity confirms that the latent variable, or construct, is unique, not just a reflection of the other variables [73].

Discriminant validity is confirmed in the structural equation modelling (SEM) based on the PLS technique, by analyzing the mean variance extracted (AVE) [69]. The average extracted variance measures the variance captured by the lantern construct, or the variance explained [69]. This is calculated using the formula:

$$
\mathrm{AVE}=\sum \lambda_{i}^{2} /\left[\sum \lambda_{i}^{2}+\sum\left(1-\lambda_{i}^{2}\right)\right]
$$

where $\lambda_{i}$ is the loading of each item within the corresponding construct [69].

The extracted mean variance values have a recommended minimum threshold of 0.5 [67]. As we can see in Table 9, the average variance extracted for each construct exceeds the critical threshold of 0.5.

Table 9. Average variance extracted.

\begin{tabular}{ccccc}
\hline Variable & Ease of Use & Perceived Usefulness & Attitude & Intention \\
\hline Average value & 0.8 & 0.729 & 0.79 & 0.829 \\
\hline
\end{tabular}

Good discriminant validity demonstrates that the question-statements (items) associated with each latent variable are not confused by the questionnaire respondents with the items of the other latent variables in terms of the meaning of each question-statement [53].

Based on Table 10 data, the values on the diagonal (corresponding to the square root of AVE) must be larger than any other value above or below it, from the same column (corresponding to the 
correlations between the latent variables) [53]. Thus, it is observed that the square roots of AVE are much larger than any correlation between two variables, fulfilling the criterion of validity.

Table 10. Correlations among latent variables with square roots of AVEs.

\begin{tabular}{ccccc}
\hline & Ease of Use & Perceived Usefulness & Attitude & Intention \\
\hline Ease of Use & 0.895 & 0.53 & 0.545 & 0.41 \\
Perceived Usefulness & 0.53 & 0.854 & 0.733 & 0.621 \\
Attitude & 0.545 & 0.733 & 0.889 & 0.639 \\
Intention & 0.41 & 0.621 & 0.639 & 0.911 \\
\hline
\end{tabular}

\section{Structural Equation Modelling (SEM)}

For testing the validity of the measurements as well as for testing the causal relationships and the moderating effect, we chose the statistical program WarpPLS, version 6.0.

The reasons for this choice lie precisely in the characteristic properties that differentiate WarpPLS from other SEM analysis programs: identifying non-linear relationships and estimating the connection coefficients accordingly, modelling both reflective and formative variables, calculating associated $p$ values, calculating the direct, indirect, and total effects and the calculation of the effect size based on Cohen's coefficients, etc. [53].

\subsection{Model Conformity Testing}

Before verifying the hypotheses based on the analysis of the path coefficients, it is necessary to validate the model by interpreting the model's compliance indicators (Table 11. Model fit and quality indices).

Table 11. Model fit and quality indices.

\begin{tabular}{cc}
\hline Model Fit Indices & Eligibility Criterion \\
\hline Average path coefficient (APC) $=0.423, p<0.001$ & $p<0.05$ \\
Average R-squared (ARS) $=0.446, p<0.001$ & $p<0.05$ \\
Average adjusted R-squared (AARS) $=0.445, p<0.001$ & $p<0.05$ \\
Average full collinearity VIF (AFVIF) $=2.108$ & acceptable if $\leq 5$, ideally $\leq 3.3$ \\
Simpson's paradox ratio (SPR) $=1.000$ & acceptable if $\geq 0.7$, ideally $=1$ \\
R-squared contribution ratio (RSCR) $=1.000$ & acceptable if $\geq 0.9$, ideally $=1$ \\
Statistical suppression ratio (SSR) $=1.000$ & $\geq 0.7$ \\
\hline Source: [74] \\
\hline
\end{tabular}

WarpPLS 6.0 generates three such compliance indicators: average path coefficient (APC), average R squared (ARS), and average variance of inflation factors (AVIF).

Ned Kock [74] recommends two criteria for testing the model's conformity: first of all, it is necessary that the $p$ values associated with the average link coefficient and of the average square $\mathrm{R}$ be less than 0.05; second, it is necessary that the value of the average variance of inflation factors be less than 5 [53].

Based on the obtained compliance indices, APC $=0.423(p<0.001)$, ARS $=0.446(p<0.001)$, and AVIF $=2.108$, we can affirm the conformity of the model, which has a good predictive and explanatory capacity. Even if AVIF has a value less than 5, it is necessary to analyze the variation of all inflation factors (VIFs) to detect the presence of multicollinearity.

The presence or absence of multicollinearity in the model is detected by the inflation factors of variation (VIF). VIF is a measure of the degree of multicollinearity existing between latent variables that is supposed to affect other latent variables [53].

There are two ways to interpret the inflation factors of the variance: a more restrictive modality, which recommends a value less than 5 , and a more permissive modality that tolerates a value less than 10 [71]. 
Following Table 12, we observe that all inflation factors are lower than 2.612, which indicates a lack of multicollinearity in the model.

Table 12. Full collinearity VIFs.

\begin{tabular}{cccc}
\hline Ease of Use & Perceived Usefulness & Attitude & Intention \\
\hline 1.503 & 2.471 & 2.612 & 1.847 \\
\hline
\end{tabular}

\subsection{Analysis of Direct Links Based on the Path Coefficients}

Path coefficient analysis, also called standardized $\beta$ coefficients, is the first step in the process of validating our hypotheses. The path coefficients represent numerical estimates of the causal relationships between two variables in a path analysis [75].

Linking coefficients involves calculating a separate regression for each structural equation, each including only the direct causal effect of the endogenous variable [75].

The path coefficients as well as the associated $p$ values are represented in Table 13. Each path coefficient is displayed within a box, where the column refers to the predictor variable [53].

Table 13. Path coefficients and $p$ values.

\begin{tabular}{|c|c|c|c|c|}
\hline & Ease of Use & Perceived Usefulness & Attitude & Intention \\
\hline Perceived Usefulness & $\begin{array}{c}0.532 \\
p<0.001\end{array}$ & & & \\
\hline Attitude & $\begin{array}{c}0.22 \\
p<0.001\end{array}$ & $\begin{array}{c}0.617 \\
p<0.001\end{array}$ & & \\
\hline Intention & & $\begin{array}{c}0.335 \\
p<0.001\end{array}$ & $\begin{array}{c}0.409 \\
p<0.001\end{array}$ & \\
\hline
\end{tabular}

The study of path coefficients and the associated $p$-values allows validation or rejection of hypotheses. Analyzing Table 13 and Figure 2, we can see that all hypotheses are verified at a significance threshold of 0.001 .

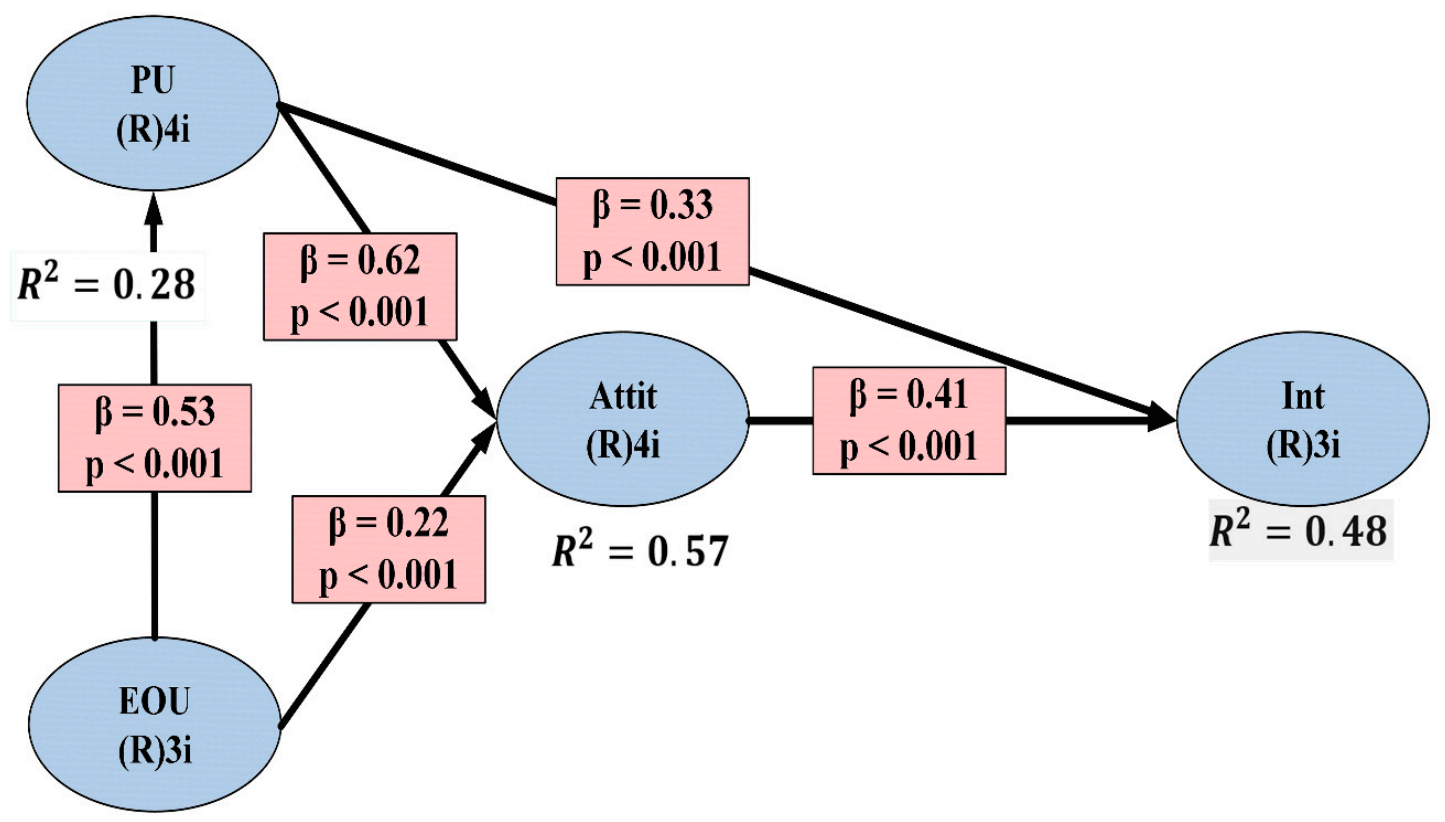

Figure 2. Model results. 
It can thus be stated that most respondents believe that they have the skills and knowledge to use eCall based on 112 IVS. Additionally, the direct and positive impact of the attitude on consumers' intention to buy eCall based on 112 IVS is validated.

Both Table 14 and Figure 2 show the main predictors of consumers 'intention to buy/use eCall IVS: consumers' attitude towards using eCall IVS (hypothesis 1), and perceived usefulness of eCall IVS (hypothesis 2). The mean square of the variable "consumers' intention to use eCall IVS" is 0.48 , which means that $48 \%$ of the intention change is due to the variation of the latent variables.

Table 14. Main hypotheses validation.

\begin{tabular}{|c|c|c|c|c|}
\hline No. & Hypothesis & $\beta$ & $p$ & Validation \\
\hline 1 & $\begin{array}{l}\text { There is a direct and positive relationship between consumers' attitude towards } \\
\text { the eCall device and their intention to use the device. }\end{array}$ & 0.409 & 0.001 & YES \\
\hline 2 & $\begin{array}{l}\text { There is a direct and positive relationship between consumers' perceptions of } \\
\text { eCall device usefulness and their intention to use the eCall device. }\end{array}$ & 0.335 & 0.001 & YES \\
\hline 3 & $\begin{array}{l}\text { There is a direct and positive relationship between consumers' perceptions of } \\
\text { eCall device usefulness and their attitude towards using the eCall device. }\end{array}$ & 0.617 & 0.001 & YES \\
\hline 4 & $\begin{array}{l}\text { There is a direct and positive relationship between consumers' perceptions of the } \\
\text { ease of use of the eCall IVS and their attitude towards the eCall device. }\end{array}$ & 0.22 & 0.001 & YES \\
\hline 5 & $\begin{array}{l}\text { There is a direct and positive relationship between consumers' perceptions of the } \\
\text { ease of use of the eCall device and their perceptions of eCall IVS usefulness. }\end{array}$ & 0.532 & 0.001 & YES \\
\hline
\end{tabular}

If direct effects of the exogenous variables on the endogenous variables can be observed within the analysis of the path coefficients, the indirect effects and total effects that involve the cumulating of the direct and indirect effects require a separate study. Table 15 shows the sum of the indirect effects, the number of paths through which the indirect effect is achieved, at a value of the significance threshold lower than 0.05 .

Table 15. Sums of indirect effects.

\begin{tabular}{|c|c|c|}
\hline & Ease of Use & Perceived Usefulness \\
\hline Attitude & $\begin{array}{c}0.328 \\
(1 \text { path }) \\
(<0.001)\end{array}$ & \\
\hline Intention & $\begin{array}{c}0.403 \\
(3 \text { paths }) \\
(<0.001)\end{array}$ & $\begin{array}{c}0.253 \\
(1 \text { path }) \\
(<0.001)\end{array}$ \\
\hline
\end{tabular}

In the previous section, we reported a direct effect of perceived usefulness (UP) on their intention to use eCall IVS (INT). However, the perceived usefulness also influences the intention indirectly through the perceived usefulness link (PU)—attitude (Attit)—intention (INT): path with 2 segments, namely UP-Att and Att-INT. This time the indirect effect of the perceived usefulness on the intention goes through the "attitude" variable.

Similarly, perceptions on ease of use indirectly influence the intention to buy through three paths, cumulating an indirect influence of 0.403, as illustrated in Table 15. By accumulating the indirect effects and the direct effects, we obtain the total effects of all latent variables on the endogenous variables.

Table 16 shows the sum of the total effects, the number of links through which the indirect effect is achieved, at a value of the significance threshold lower than 0.05 . However, by only analyzing the standardized $\beta$ coefficients, we cannot estimate the magnitude of the effect of an exogenous variable on an endogenous variable. For such a prediction, it is necessary to calculate the effect size. The statistical program WarpPLS calculates the coefficients of the effect size based on Cohen's $f$ squared coefficients, by which the effect size can be determined based on the recommended values of $0.02,0.15$, and 0.35 for a small, medium, and large effect [76]. 
Table 16. Analysis of total effects.

\begin{tabular}{cccc}
\hline & Ease of Use & Perceived Usefulness & Attitude \\
\hline Perceived Usefulness & $0.532(1)$ & & \\
Attitude & $0.549(2)$ & $0.617(1)$ & \\
Intention & $0.403(3)$ & $0.588(2)$ & $0.409(1)$ \\
\hline
\end{tabular}

From the information in Table 17, it can be stated that the effect of perceived usefulness on consumers' intention to buy eCall IVS as well as the effect of perceived usefulness on the attitude towards the eCall IVS are large effects that exceed the threshold of 0.35. Medium effects on consumers' intention to buy eCall IVS are posed by ease of use and attitude towards eCall IVS, with values above 0.15. Small and negligible effects on consumers' intention to buy/use eCall are not present.

Table 17. Effect sizes for total effects.

\begin{tabular}{ccccc}
\hline & Ease of Use & Perceived Usefulness & Attitude & Intention \\
\hline Perceived Usefulness & 0.283 & & & \\
Attitude & 0.3 & 0.453 & & \\
Intention & 0.165 & 0.373 & 0.268 & \\
\hline
\end{tabular}

\section{Results and Discussion}

The study of consumers' intention to buy/use eCall IVS implies a conclusive research. Descriptive research was used to describe the socio-demographic characteristics and habits of European drivers (Respondent profile) and to establish the drivers' opinions and perceptions regarding various aspects of the investigated phenomenon, namely the use of eCall IVS, while causal research was used to test the hypotheses regarding the causal relationships between the proposed variables.

The first step in the analysis of the data collected through the online survey was the examination and validation of the data based on several important considerations. Structural equation modelling (SEM) was used, based on variance analysis (PLS), an analysis technique that does not imply the existence of a normal data distribution.

Before conducting the SEM analysis, the descriptive statistics were also examined. As far as the European driver's profile is concerned, the gender distribution is about equal. Not the same can be said about the distribution by age categories, vehicle type, or age of the car. Two age categories make up the majority of drivers: $16-30$ years old and 31-40 years old. As for the type of vehicle, most drive passenger cars (car or taxi). Regarding the age of the car, most vehicles are under 5 years old (242), followed by vehicles more than 5 but less than 10 (223), and those more than 10 but less than 15 (190). The representativeness of the sample for the entire population was emphasized due to the evidence from its comparison with two reference samples.

While descriptive statistics provide interesting insights into the socio-demographic characteristics of drivers and their habits, the main purpose of data analysis was to test and validate the causal relationships proposed in the conceptual model from the research design phase. The first step of the SEM analysis was to test the accuracy of the measurements, since each measuring instrument has a certain amount of measurement error, which represents a threat to the validity of the empirical results [58] (p. 421). Measurement accuracy was confirmed by testing both the accuracy of the measurements and their validity.

Convergent validity was tested with the statistical software WarpPLS, version 6.0, which generates the factor loadings and the cross loadings based on the structure matrix, the template matrix rotated by the oblique rotation method, also called Promax, and a combination of the two types of matrices. It is observed that each set of items is loaded very well within its defined construct, while the cross-loading is very small, which leads to the acceptance of a good convergent validity of the measurements used.

Divergent validity, the extent to which one latent variable differs from the other latent variables existing in the model [56], was tested following the approach of Fornel and Larcker [67]. From the 
correlation matrix of the latent variables, the square roots of the average variance extracted (AVE) were compared with the common variance between constructs, and it was shown that each square root of the AVE is greater than any correlation existing between the latent variable and any other latent variable of the model.

We tested the 5 main hypotheses of the study by analyzing the path coefficients within the structural model, but not before testing the conformity of the model by studying specific indicators. Based on the obtained compliance indices, APC $=0.423(p<0.001)$, ARS $=0.446(p<0.001)$, and AVIF $=1.779$, we can affirm the conformity of the model, which has a good predictive and explanatory capacity. To confirm the hypotheses of the research, we resorted to structural equation modelling (SEM), based on the analysis of variance: PLS- partial least squares. Through the analysis of the path coefficients (standardized $\beta$ coefficients), we were able to validate all the causal relationships of the initially proposed conceptual model, and the path coefficients were significant at a chosen significance threshold of $p<0.01$.

The analysis of the path coefficients was extremely useful in validating the primary hypotheses of the research, but they only considered the direct effect of the exogenous variables on the endogenous variables. Due to the complexity of the model and given the existence of variables with mediating effect, it was necessary to include the study of indirect effects. Thus, the existence of indirect effects on the consumers' intention to use eCall IVS with statistically significant effects was observed. One example is the existence of fundamental consumer beliefs that directly and indirectly influence behavioral intention (this is the case of consumer beliefs about the eCall IVS usefulness, which not only directly influences the behavioral intention with a path coefficient of 0.33 but also indirectly, with a coefficient of 0.253 through links between variables). Therefore, perceived usefulness is a good predictor of behavioral intention, and it is likely that promotional messages stressing usefulness aspects of the eCall system will generate higher acceptance to buy/use it. The direct effects and the indirect effects were added, thus obtaining the total effects on the endogenous variables.

By analyzing the path coefficients, we have identified the main factors with direct effect on the consumers' intention to purchase eCall IVS, namely the attitude towards the eCall IVS and the perceived usefulness. Therefore, to strengthen acceptance of the aftermarket IVS, emphasis should be placed on time saving in case of an accident, benefits in helping the driver act appropriately in case of collision, as well as the increased safety of a car equipped with such systems.

\section{Conclusions and Implications}

A direct and positive connection between consumers' attitude towards eCall IVS and behavioral intention was demonstrated by analyzing direct links. The obtained results reveal that consumers' intention to buy/use IVS depends on the extent to which they believe that eCall IVS is a good idea, beneficial, makes sense, and represents a wise decision.

A direct and positive connection between perceived usefulness and behavioral intention was demonstrated by analyzing direct paths. The more the driver perceives a greater usefulness of the eCall IVS, by saving time in case of an emergency, by aiding them to act appropriately in case of collision/car crash, and by giving them a feeling of safety, the more they manifest the intention to use/buy it. However, the usefulness perceived by drivers influences the intention to use/buy, not only directly, but indirectly through another variable. Cumulating the direct effect with the indirect effect, a total effect of $\beta=0.588$ was obtained, with a high magnitude (Table 16).

The level of explained variance in the present study is somewhat superior to previous work predicting intentions of using in-vehicle systems, such as acceptance of systems or applications that reduce mobile phone use while driving [77], and similar to acceptance of autonomous vehicle adoption [78].

Analyzing the previous results achieved in the field of eCall IVS, one can state that each approach has brought a new contribution to the current state of knowledge. Consequently, the integration of these approaches into a single conceptual framework gives a much more complete picture of a driver's 
acceptance to use an aftermarket eCall IVS. Therefore, we emphasize a first theoretical contribution of this research: testing and validating a model of consumers' intention to purchase an eCall IVS, with explanatory and predictive power. An integrative model of driver acceptance of aftermarket eCall IVS also serves as a starting point in future studies. Although TAM is frequently used in other fields, recent theoretical research is limited in the field of in-vehicle systems acceptance at European level. This could be explained by the fact that previous use of eCall systems was not by choice, since new vehicle models come pre-equipped with the technology.

It is necessary to differentiate between two concepts, and to highlight the relationship between them. We treated attitude as a pre-purchase belief of the consumer, being influenced by existing perceptions of eCall systems. Consumers initially form an attitude towards the idea of buying an eCall IVS based on information from friends, family, and the media. It is not necessary for a consumer to purchase the device to form an attitude towards the eCall IVS. Nevertheless, like any belief, it changes as a result of experience. After having made a purchase, consumers might change their pre-purchase attitude.

A favorable attitude can become unfavorable due to negative experiences and a favorable attitude can be strengthened due to the satisfaction felt after making the decision to use/purchase, as it has been also remarked in [79]. For instance, in this pre-purchase stage, we have identified that the majority of respondents were willing to pay between 80 and 100 Euros to own an aftermarket eCall IVS (survey item 24), neither with a tendency to neither agree nor disagree to pay 150 Euros (survey item 25). However, if we are to consider only owners of vehicles older than five years, they will be willing to pay up to 120 Euros on average, as well as those who own vehicles older than 10, but less than 15 years. As more drivers gain information or encounter cars already equipped with the aftermarket eCall IVS, price sensitivity might decrease.

A theoretical contribution is the analysis of the indirect and total effects. We did not find a study that considers the indirect effects and combines them with the direct effects (obtained from the analysis of path coefficients) to formulate conclusions based on the total effects. We have considered that one variable can influence not only the intention to use/purchase directly, but also indirectly through other variables. We considered that a variable can also have an indirect effect, an effect that cannot be observed by analyzing direct relationships.

Government agencies can also contribute to improving eCall adoption. As an example of facilitating sustainable rescue operations, governments can speed the local development of public safety answering points infrastructure, 5G networks infrastructure, and even training programs on road safety that might influence potential users' perceptions of usefulness and ease of use towards the eCall systems.

The implementation of eCall systems for aftermarket vehicles requires changes at several levels, for rescue operations to become sustainable, even though it alone is meant to reduce fatalities by providing much needed information about the context of an accident. This is also a reason why the European Commission has funded research for eCall system aftermarket implementation for vehicles, instead of waiting for these devices to become more predominant at the pace of vehicle stock renewal. Therefore, in the case of aftermarket retrofitting, this quickened process will impact public service answering point networks, wireless infrastructures, and human resources.

A continuation of research in gender differences in eCall IVS acceptance would be welcome, it is not possible at the current sample size to ensure relevant results, although gender-related factors could reveal solutions that aid in ensuring sustainable rescue operations as a result of eCall technology implementation and the measures required for it. Our aim was to use a representative sample at the overall European Union level, as the European Union approved and financed our research project proposal under the Connected Europe Fund Annual Programme, requiring us, as a part of the project, to assess the intention at the overall European Union level to accept having an aftermarket eCall device installed in their passenger vehicles. An extension to gender differences, other vehicle types, and representative samples at each country's level would contribute to our research. Therefore, given the important economic and social differences between EU countries, 
future multi-group analysis studies performed on samples at a representative level per country will be considered for future research.

Supplementary Materials: The following are available online at http://www.mdpi.com/2071-1050/12/22/9488/s1: S1: The Structure of the Online Questionnaire, Table S1: Distribution of respondents by country.

Author Contributions: Conceptualization: A.P.-M. and D.Z.; data curation: J.-L.S. and A.P.; formal analysis: A.P.-M. and D.Z.; investigation: A.P.-M. and J.-L.S.; methodology: A.P.-M. and D.Z.; supervision: G.C.; writing-original draft: A.P.-M. and D.Z.; writing - review and editing: A.P.-M. and A.P. All authors have read and agreed to the published version of the manuscript.

Funding: The research described in this paper was founded by the sAFE-Aftermarket eCall For Europe project, implemented under the Connected Europe Fund Annual Programme, Grant agreement Number 2018-EU-TM-0079-S, which aims to define the standards and specifications to pave the way for deployment of after-market systems for eCall.

Acknowledgments: The article processing charge (APC) was discounted integrally by the Multidisciplinary Digital Publishing Institute (MDPI).

Conflicts of Interest: The authors declare no conflict of interest.

\section{References}

1. Directorate-General for Mobility and Transport; Directorate DG-MOVE; Unit C2-Road Safety; European Commission B-1049 Brussels. Study on the Inclusion of eCall in the Periodic Roadworthiness Testing of Motor Vehicles: Final Report; MOVE/C2/SER/2017-282-SI.772101; Schulz, W.H., Schröder, R., Bönninger, D., Fernández, E., Gaillet, J.F., Sogodel, V., Scheler, S., Eds.; Publications Office of the European Union: Luxembourg, 2019; ISBN 978-92-79-99990-1. Available online: https://citainsp.org/wpcontent/uploads/2019/ 02/eCall.pdf (accessed on 8 October 2019). [CrossRef]

2. Zirra, D.; Perju-Mitran, A.; Caruţaşu, G.; Pîrjan, A.; Garais, E.G.G. An analysis of the socio-economic and human life impact of implementing the eCall In Vehicle System (IVS) in the purpose of ensuring sustainable, improved rescue operations on European roads. Sustainability 2020, 12, 5341. [CrossRef]

3. Apak, A.; Üstoglu, I. Cost Model Approach for Next Generation Emergency Call Systems-Italy Case Study; In Proceedings of the International Conference on Vehicle Technology and Intelligent Transport Systems-Volume 1: VEHITS; Institute for Systems and Technologies of Information, Control and Communication (INSTICC): Rome, Italy, 2016; pp. 130-137.

4. Campillo, P.; Velin, T.; Franco, J.J.; Arques, P. Drones, Ecall and Cyber Physical Systems for Public Safety: Answering Points 112. In Proceedings of the 12th European Conference on Software Architecture: Companion Proceeding, Madrid, Spain, 24-28 September 2018; pp. 1-2.

5. Markakis, E.K.; Lykourgiotis, A.; Politis, I.; Dagiuklas, A.; Rebahi, Y.; Pallis, E. EMYNOS: Next generation emergency communication. IEEE Commun. Mag. 2017, 55, 139-145. [CrossRef]

6. Chochliouros, I.P.; Spiliopoulou-Chochliourou, A.S.; Lalopoulos, G.K. Emergency Call (eCall) Services Based on Approved E-112 Regulations and Infrastructures: A Solution to Improve Security and Release of Road Help; In Proceedings of the FITCE Congress 2005, Vienna, Austria: 44th European Telecommunications Congress; TCN UK Limited: London, UK, 2005; pp. 76-84.

7. Petroșanu, D.-M.; Căruțașu, G.; Căruțașu, N.L.; Pîrjan, A. A review of the recent developments in integrating machine learning models with sensor devices in the smart buildings sector with a view to attaining enhanced sensing, energy efficiency, and optimal building management. Energies 2019, 12, 4745. [CrossRef]

8. Duffett, R.; Petroșanu, D.-M.; Negricea, I.-C.; Edu, T. Effect of YouTube Marketing Communication on Converting Brand Liking into Preference among Millennials Regarding Brands in General and Sustainable Offers in Particular. Evidence from South Africa and Romania. Sustainability 2019, 11, 604. [CrossRef]

9. Davis, F.D.; Bagozzi, R.P.; Warshaw, P.R. User acceptance of computer technology: A comparison of two theoretical models. Manag. Sci. 1989, 35, 982-1003. [CrossRef]

10. Thompson, R.L.; Higgins, C.A.; Howell, J.M. Personal computing: Toward a conceptual model of utilization. MIS Q. 1991, 15, 125-143. [CrossRef]

11. Lai, P.C. The literature review of technology adoption models and theories for the novelty technology. JISTEM J. Inf. Syst. Technol. Manag. 2017, 14, 21-38. [CrossRef] 
12. Taherdoost, H. A review of technology acceptance and adoption models and theories. Procedia Manuf. 2018, 22, 960-967. [CrossRef]

13. Triandis, H. Interpersonal Behaviour; Brooks/Cole Pub. Co.: Monterey, CA, USA, 1977.

14. Bandura, A. Social Learning Theory; Prentice-Hall: Englewood Cliffs, NJ, USA, 1977; ISBN 0-13-816751-6.

15. Ajzen, I. The theory of planned behavior. Organ. Behav. Hum. Decis. Process. 1991, 50, 179-211. [CrossRef]

16. Moore, G.C.; Benbasat, I. Integrating diffusion of innovations and theory of reasoned action models to predict utilization of information technology by end-users. In Diffusion and Adoption of Information Technology; Springer: Berlin/Heidelberg, Germany, 1996; pp. 132-146.

17. Davis, F.D.; Bagozzi, R.P.; Warshaw, P.R. Extrinsic and intrinsic motivation to use computers in the workplace 1. J. Appl. Soc. Psychol. 1992, 22, 1111-1132. [CrossRef]

18. Rogers, E.M. Diffusion of Innovations: Modifications of a model for telecommunications. In Die Diffusion Von Innovationen in Der Telekommunikation; Springer: Berlin/Heidelberg, Germany, 1995; pp. 25-38.

19. Goodhue, D.L.; Thompson, R.L. Task-technology fit and individual performance. MIS Q. 1995, 19, $213-236$. [CrossRef]

20. Taylor, S.; Todd, P.A. Understanding information technology usage: A test of competing models. Inf. Syst. Res. 1995, 6, 144-176. [CrossRef]

21. Venkatesh, V.; Davis, F.D. A theoretical extension of the technology acceptance model: Four longitudinal field studies. Manag. Sci. 2000, 46, 186-204. [CrossRef]

22. Venkatesh, V.; Morris, M.G.; Davis, G.B.; Davis, F.D. User acceptance of information technology: Toward a unified view. MIS Q. 2003, 27, 425-478. [CrossRef]

23. Venkatesh, V.; Bala, H. Technology acceptance model 3 and a research agenda on interventions. Decis. Sci. 2008, 39, 273-315. [CrossRef]

24. Bouten, M. Compatibility and Technology Acceptance: Consolidating, Validating and Extending Concep; Faculty of Economics and Business Administration, Maastricht University: Maastricht, The Netherlands, 2008.

25. Wu, K.; Zhao, Y.; Zhu, Q.; Tan, X.; Zheng, H. A meta-analysis of the impact of trust on technology acceptance model: Investigation of moderating influence of subject and context type. Int. J. Inf. Manag. 2011, 31, 572-581. [CrossRef]

26. Lai, P. Design and Security impact on consumers' intention to use single platform E-payment. Interdiscip. Inf. Sci. 2016, 22, 111-122. [CrossRef]

27. Wang, M.-M.; Wang, J.-J. Understanding Solvers' Continuance Intention in Crowdsourcing Contest Platform: An Extension of Expectation-Confirmation Model. J. Theor. Appl. Electron. Commer. Res. 2019, 14, 17-33. [CrossRef]

28. Akel, G.; Armağan, E. Hedonic and utilitarian benefits as determinants of the application continuance intention in location-based applications: The mediating role of satisfaction. Multimed. Tools Appl. 2020, 1-22. [CrossRef]

29. Sun, H.; Zhang, P. A methodological analysis of user technology acceptance. In Proceedings of the 37th Annual Hawaii International Conference on System Sciences, Big Island, HI, USA, 5-8 January 2004; IEEE: Piscataway, NJ, USA, 2004.

30. Feng, G.C.; Su, X.; Lin, Z.; He, Y.; Luo, N.; Zhang, Y. Determinants of technology acceptance: Two model-based meta-analytic reviews. J. Mass Commun. Q. 2020. [CrossRef]

31. Chuttur, M.Y. Overview of the technology acceptance model: Origins, developments and future directions. Work. Pap. Inf. Syst. 2009, 9, 9-37.

32. Opoku, M.O.; Francis, E.-K. Relevance of The Technology Acceptance Model (Tam) in Information Management Research: A Review of Selected Empirical Evidence. Res. J. Bus. Manag. 2019, 7, 34-44. [CrossRef]

33. Orzan, G.; Macovei, O.I.; Iconaru, C.; Perju, A. An Empirical Tam-Based Model of Romanian Sme's Intention to Continue Using Online Marketing Techniques. Metal. Int. 2012, 17, 147.

34. Perju-Mitran, A.; Negricea, C.I. Modelling the Influence of Online Marketing Communication on Behavioural Intentions. Netw. Intell. Stud. 2014, 245-253.

35. Schepers, J.; Wetzels, M. A meta-analysis of the technology acceptance model: Investigating subjective norm and moderation effects. Inf. Manag. 2007, 44, 90-103. [CrossRef]

36. Fishbein, M.; Ajzen, I. Belief, Attitude, Intention, and Behavior: An Introduction to Theory and Research; Penn State University Press: University Park, PA, USA, 1977. [CrossRef] 
37. Eurostat. Stock of Vehicles by Category and NUTS 2 Regions; Eurostat: Luxembourg, 2019. Available online: https://appsso.eurostat.ec.europa.eu/nui/show.do?dataset=tran_r_vehst\&lang=en (accessed on 20 May 2020).

38. European Commission. Communication to the European Parliament, the Council, the European Economic and Social Committee and the Committee of the Regions. In Europe on the Move, Sustainable Mobility for Europe: Safe, Connected and Clean; Annex 1: Strategic Action Plan on Road Safety; European Commission, European Transport Safety Council, B-1040 Brussels: Brussels, Belgium, 2018. Available online: https://ec. europa.eu/transparency/regdoc/rep/1/2018/EN/COM-2018-293-F1-EN-ANNEX-1-PART-1.PDF (accessed on 26 October 2019).

39. Adminaité-Fodor, D.; Heilpern, C.; Jost, G. Ranking EU Progress on Road Safety. 13th Road Safety Performance Index Report; ETSC: Brussels, Belgium, 2019. Available online: https://etsc.eu/wp-content/uploads/AR_2019Final.pdf (accessed on 2 May 2020).

40. Khare, A.; Rakesh, S. Antecedents of online shopping behavior in India: An examination. J. Internet Commer. 2011, 10, 227-244. [CrossRef]

41. Ajzen, I. From intentions to actions: A theory of planned behavior. In Action Control; Springer: Berlin/Heidelberg, Germany, 1985; pp. 11-39.

42. Hrubes, D.; Ajzen, I.; Daigle, J. Predicting hunting intentions and behavior: An application of the theory of planned behavior. Leis. Sci. 2001, 23, 165-178. [CrossRef]

43. Ajzen, I. Perceived behavioral control, self-efficacy, locus of control, and the theory of planned behavior 1 . J. Appl. Soc. Psychol. 2002, 32, 665-683. [CrossRef]

44. Al-Gahtani, S.S. Modeling the electronic transactions acceptance using an extended technology acceptance model. Appl. Comput. Inform. 2011, 9, 47-77. [CrossRef]

45. Rodríguez Del Bosque, I.; Herrero Crespo, Á. How do internet surfers become online buyers? An integrative model of e-commerce acceptance. Behav. Inf. Technol. 2011, 30, 161-180. [CrossRef]

46. Davis, F.D. User acceptance of information technology: System characteristics, user perceptions and behavioral impacts. Int. J. Man Mach. Stud. 1993, 38, 475-487. [CrossRef]

47. Ajzen, I.; Fishbein, M. The influence of attitudes on behavior. In The Handbook of Attitudes; Lawrence Erlbaum Associates: Mahwah, NJ, USA, 2005; pp. 173-222.

48. Fishbein, M.; Stasson, M. The Role of Desires, Self-Predictions, and Perceived Control in the Prediction of Training Session Attendance 1. J. Appl. Soc. Psychol. 1990, 20, 173-198. [CrossRef]

49. Babbie, E. The Basics of Social Research; CENGAGE Learning: Belmont, CA, USA, 2010.

50. Jackson, S.L. Research Methods and Statistics a Critical Thinking Approach, 2nd ed.; Cengage Learning: Belmont, CA, USA, 2011.

51. Allison, P.D. Missing Data; Series: Quantitative Applications in the Social Sciences; Sage Publications: Los Angeles, CA, USA, 2002; ISBN 0-7619-1672-5.

52. Kline, R.B. Principles and Practice of Structural Equation Modeling; Guilford Publications: New York, NY, USA, 2015; ISBN 1462523358.

53. Kock, N. WarpPLS 5.0 User Manual; Script Warp Systems: Laredo, TX, USA, 2015.

54. Hair, J.F.; Ringle, C.M.; Sarstedt, M. PLS-SEM: Indeed a silver bullet. J. Mark. Theory Pract. 2011, 19, $139-152$. [CrossRef]

55. Marcoulides, G.A.; Chin, W.W.; Saunders, C. A critical look at partial least squares modeling. MIS Q. 2009, 33, 171-175. [CrossRef]

56. Shiau, W.-L.; Sarstedt, M.; Hair, J.F. Internet research using partial least squares structural equation modeling (PLS-SEM). Internet Res. 2019, 29, 398-406. [CrossRef]

57. Fink, A.; Litwin, M.S. How to Measure Survey Reliability and Validity; Sage Publications: Los Angeles, CA, USA, 1995. [CrossRef]

58. Bagozzi, R.P.; Yi, Y.; Phillips, L.W. Assessing construct validity in organizational research. Adm. Sci. Q. 1991, 36, 421-458. [CrossRef]

59. Zeanah, C.H. Handbook of Infant Mental Health, 4th ed.; Guilford Publications: New York, NY, USA, 2018; ISBN 1462537111.

60. Hood, A.B.; Johnson, R.W. Assessment in Counseling: A Guide to the Use of Psychological Assessment Procedures; American Association for Counseling: Alexandria, VA, USA, 1991; ISBN 1556200749.

61. Dörnyei, Z.; Taguchi, T. Questionnaires in Second Language Research: Construction, Administration, and Processing; Routledge: Abingdon, UK, 2009; ISBN 1135262519. 
62. Wood, M.J.; Ross-Kerr, J. Basic Steps in Planning Nursing Research: From Question to Proposal, 7th ed.; Jones and Bartlett Publishers: Mississauga, ON, Canada, 2011; ISBN 0763771791.

63. De Vellis, R.F. Scale Development: Theory and Applications; Sage Publications: Los Angeles, CA, USA, 2016; Volume 26, ISBN 1506341551.

64. Kent, R. Data Construction and Data Analysis for Survey Research; Macmillan: New York, NY, USA, 2001; ISBN 0333763068.

65. Nunnally, J.C. Psychometric Theory 3E; Tata Mcgraw-Hill Education: New York, NY, USA, 1994; ISBN 0071070885.

66. Leech, N.L.; Barrett, K.C.; Morgan, G.A. IBM SPSS for Intermediate Statistics: Use and Interpretation, 5th ed.; Routledge: Abingdon, UK, 2014; ISBN 1136334947.

67. Fornell, C.; Larcker, D.F. Structural equation models with unobservable variables and measurement error: Algebra and statistics. J. Mark. Res. 1981, 18, 382-388. [CrossRef]

68. Rubin, A.; Babbie, E.R. Empowerment Series: Research Methods for Social Work; Cengage Learning: Boston, MA, USA, 2016; ISBN 1305633822.

69. Gefen, D.; Straub, D. A practical guide to factorial validity using PLS-Graph: Tutorial and annotated example. Commun. Assoc. Inf. Syst. 2005, 16, 5. [CrossRef]

70. Jewell, D.V. Guide to Evidence-Based Physical Therapist Practice, 2nd ed.; Jones \& Bartlett Learning: Mississauga, ON, Canada, 2011; ISBN 076377765X.

71. Hair, J.F.; Anderson, R.E.; Tatham, R.L. Multivariate Data Analysis; Macmillan: New York, NY, USA, 1987; ISBN 0023489804.

72. Farrell, A.M. Insufficient discriminant validity: A comment on Bove, Pervan, Beatty, and Shiu (2009). J. Bus. Res. 2010, 63, 324-327. [CrossRef]

73. Churchill, G.A. Marketing Research, Methodological Foundations, 4th ed.; The Dryden Press: Chicago, IL, USA, 1987.

74. Kock, N. Factor-based structural equation modeling with WarpPLS. Australas. Mark. J. 2019, 27, 57-63. [CrossRef]

75. Olobatuyi, M.E. A User's Guide to Path Analysis; University Press of America: Lanham, MD, USA, 2006; ISBN 0761832300.

76. Cohen, J. Statistical Power Analysis for the Behavioral Sciences; Lawrence Erlbaum: Hillsdale, NJ, USA, 1988; ISBN 0805802835.

77. Oviedo-Trespalacios, O.; Briant, O.; Kaye, S.-A.; King, M. Assessing driver acceptance of technology that reduces mobile phone use while driving: The case of mobile phone applications. Accid. Anal. Prev. 2020, 135, 105348. [CrossRef] [PubMed]

78. Yuen, K.F.; Cai, L.; Qi, G.; Wang, X. Factors influencing autonomous vehicle adoption: An application of the technology acceptance model and innovation diffusion theory. Technol. Anal. Strateg. Manag. 2020, 1-15. [CrossRef]

79. Mladineo, N.; Knezic, S.; Jajac, N. Decision Support System for emergency management on motorway networks. Transportmetrica 2011, 7, 45-62. [CrossRef]

Publisher's Note: MDPI stays neutral with regard to jurisdictional claims in published maps and institutional affiliations.

(C) 2020 by the authors. Licensee MDPI, Basel, Switzerland. This article is an open access article distributed under the terms and conditions of the Creative Commons Attribution (CC BY) license (http://creativecommons.org/licenses/by/4.0/). 